\title{
The epidemiology and management of postmenopausal osteoporosis: a viewpoint from Brazil
}

\author{
Luiz Francisco Baccaro' \\ Délio Marques Conde ${ }^{2}$ \\ Lúcia Costa-Paiva' \\ Aarão Mendes Pinto-Neto' \\ 'Department of Gynecology, State \\ University of Campinas (UNICAMP), \\ Campinas, São Paulo, Brazil; ${ }^{2}$ Breast \\ Clinic, Hospital for Maternal \\ and Child Healthcare, Goiânia, \\ Goiás, Brazil
}

This article was published in the following Dove Press journal:

Clinical Interventions in Aging

20 March 2015

Number of times this article has been viewed

\begin{abstract}
Brazil has an aging population, with an associated increase in the prevalence of chronic diseases. Postmenopausal osteoporosis is of particular concern because it leads to an increased risk of fractures, with subsequent negative impacts on health in older women. In recent years, efforts have been made to better understand the epidemiology of osteoporosis in Brazil, and to manage both direct and indirect costs to the Brazilian health care system. The reported prevalence of osteoporosis among postmenopausal women in Brazil varies from $15 \%$ to $33 \%$, depending on the study methodology and the use of bone densitometry data or self-reporting by participants. A diagnosis of osteoporosis can be made on the basis of fractures occurring without significant trauma or on the basis of low bone mineral density measured by dual energy X-ray absorptiometry. To reduce the risk of osteoporosis, all postmenopausal women should be encouraged to maintain a healthy lifestyle, which includes physical activity and a balanced diet. Smoking and alcohol use should also be addressed. Special attention should be given to interventions to reduce the risk of falls, especially among older women. Calcium intake should be encouraged, preferably through diet. The decision to recommend calcium supplementation should be made individually because there is concern about a possible increased risk of cardiovascular disease associated with this treatment. Brazilian women obtain a minimal amount of vitamin D from their diet, and supplementation is warranted in women with little exposure to solar ultraviolet-B radiation. For women diagnosed with osteoporosis, some form of pharmacologic therapy should be initiated. Compliance with treatment should be monitored, and the treatment period should be individualized for each patient. The Brazilian government provides medication for osteoporosis through the public health system free of charge, but without proper epidemiological knowledge, the implementation of public health programs is impaired.
\end{abstract}

Keywords: menopause, public health, preventive medicine, risk factors, disease management

\section{Introduction}

The Brazilian population has aged considerably over the past few decades. Data from the population census indicate an inversion of the national age pyramid. It is estimated that by the year 2050 , the elderly will account for $23 \%$ of the population, and children aged $0-14$ years will account for only $13 \%$ of the population. ${ }^{1}$ As a population ages, the epidemiology of disease changes. In the past, acute infectious diseases accounted for the vast majority of health problems. Currently, chronic diseases have an increasingly important impact on the lives of the Brazilian people. ${ }^{2}$ Therefore, physicians should keep up to date with the management of the chronic diseases that are common in an aging population. Among these chronic diseases, postmenopausal osteoporosis is of particular importance because of its potentially harmful consequences to health
Correspondence: Luiz Francisco Baccaro Department of Gynecology, State University of Campinas (UNICAMP), Rua Alexander Fleming, I0I, Cidade Universitária Zeferino Vaz, Campinas, |3.083-88| São Paulo, SP, Brazil

Tel +55 I 95219306

$\mathrm{Fax}+551935219306$

Email luiz.baccaro@gmail.com 
in elderly women and the fact that relatively simple treatments can change the natural history of the disease.

Osteoporosis is a chronic disease, defined as a skeletal disorder characterized by decreased bone strength, which predisposes affected individuals to fractures. ${ }^{3}$ A diagnosis of osteoporosis can be made on the based of either fractures occurring without significant trauma or low bone mineral density measured by dual energy X-ray absorptiometry (DXA). ${ }^{4}$ Most women with osteoporosis are asymptomatic, which makes epidemiological research especially difficult. In Brazil, a large country with extremely diverse characteristics from region to region, accurately determining the prevalence of osteoporosis is a complicated task. In recent years, efforts have been made to better understand the epidemiology of postmenopausal osteoporosis and to manage both the direct and the indirect costs of the disease to the Brazilian health care system. ${ }^{5}$ In this article, we review recent studies of the epidemiology and management of postmenopausal osteoporosis, with a particular focus on the situation in Brazil.

\section{Epidemiology of osteoporosis in Brazil}

The reported prevalence of postmenopausal osteoporosis in Brazil is highly variable because of differences in the study methodology, the selection of study participants, and the definition of the disease. In a study by Camargo et $a l^{6}$ published in 2005, which included 207 women aged $>70$ years, osteoporosis was diagnosed by bone densitometry and classified according to World Health Organization (WHO) criteria. The prevalence of osteoporosis ranged from $22.2 \%$ to $33.2 \%$, depending on the bone evaluated. ${ }^{6}$ A study by Martini et $\mathrm{al}^{7}$ published in 2009, used data from a telephone survey on chronic diseases (Vigilância de fatores de risco e proteção para doenças crônicas por inquérito telefônico [Protective and Risk Factors for Chronic Diseases by Telephone Survey]). Interviews were conducted with 54,369 individuals aged $\geq 18$ years, and the presence of osteoporosis was determined on the basis of self-reporting by participants. The prevalence of osteoporosis was $8 \%$ in women aged 45-54 years, $19.2 \%$ in women aged 55-64 years, and $32.7 \%$ in women $>65$ years. $^{7}$ In 2010 , Pinheiro et $\mathrm{al}^{8}$ published the results of a household survey, the Brazilian Osteoporosis Study (BRAZOS), which included a representative sample of women from all regions of Brazil. Again, the diagnosis of osteoporosis was based on self-reporting by participants. In this survey, 1,695 women aged $>40$ years were interviewed, and of these approximately $35 \%$ were premenopausal. For postmenopausal women, the average age of the last menstrual period was
$47 \pm 5.1$ years. The prevalence of osteoporosis was reported as $15.1 \%{ }^{8}$ In 2010 , Pinheiro et $\mathrm{al}^{9}$ also conducted a crosssectional study that included 4,332 women aged $>40$ years in São Paulo (São Paulo Osteoporosis Study [SAPOS]). The diagnosis of osteoporosis was made by DXA, and the prevalence of postmenopausal osteoporosis was 33\%. ${ }^{9}$ In 2011 , Buttros et $\mathrm{al}^{10}$ reported a prevalence of $24.6 \%$ from a crosssectional study of 431 women aged 40-75 years with osteoporosis diagnosed by DXA. More recently, in 2013, Baccaro et $\mathrm{al}^{11}$ published the results of a population-based household survey that included 622 women aged $>50$ years. The prevalence of osteoporosis based on self-reporting was $21.3 \%$, but only $16.7 \%$ of the participants reported that the diagnosis of osteoporosis had been made by bone densitometry.

As demonstrated by these studies, the prevalence of osteoporosis in Brazil varies widely according to the study methodology. Some studies based the diagnosis of osteoporosis on bone densitometry data and others relied on self-reporting by participants. Furthermore, there are few studies that include a representative sample of the population from all regions of the country. Overall, depending on age and the characteristics of the study population, the reported prevalence of osteoporosis in Brazilian women varies from $15 \%$ to $33 \%$. A recent study on the epidemiology of osteoporosis in the United States found a prevalence of $15.4 \%$ among women older than 50 years and a prevalence of $34.9 \%$ among women older than 80 years. ${ }^{12}$ Therefore, despite the limitations related to a lack of uniformity of national studies, the percentage of Brazilian women living with osteoporosis appears to be similar to that in other populations.

\section{Factors associated with postmenopausal osteoporosis}

Recent national studies have identified some of the factors associated with osteoporosis among Brazilian women. In their study published in 2009, Martini et al ${ }^{7}$ reported a positive association between osteoporosis and age $>45$ years, not being single, height in the third quartile, and being a former smoker. Women with higher education and those who were not white had a lower prevalence of osteoporosis. ${ }^{7}$ In the SAPOS study, the main factors associated with low bone mineral density were advanced age, menopause, a history of prior fracture, and being a smoker. Women with a higher body mass index who performed regular physical activity and received hormone replacement therapy had a lower prevalence of low bone mineral density. ${ }^{9}$ Recently, Baccaro et a ${ }^{11}$ reported that osteoarthritis, a longer time since menopause, balance problems, impaired functional capacity, and poorer self-perception 
of health were associated with a higher prevalence of osteoporosis. In the same study, presenting with poorer self-perception of health, treatment with natural remedies for menopause, smoking more than one pack of cigarettes per day (currently or in the past), and impaired functional capacity were factors associated with early onset of the disease. ${ }^{11}$

A number of dietary factors are known to be associated with decreased bone mineral density. A low intake of calcium can lead to increased resorption of the bone matrix with demineralization and a consequent increase in fracture risk. International societies recommend a daily intake of calcium of 1,200-2,000 mg per day. ${ }^{13}$ However, many Brazilian women do not have an adequate dietary calcium intake. Data from the BRAZOS study indicated that the average daily calcium intake among Brazilian women was approximately $400 \mathrm{mg}$ per day, which may contribute to an increase in the frequency of diseases resulting from bone demineralization. ${ }^{14}$

Vitamin D is a prosteroid hormone that plays an essential role in the metabolism of calcium and phosphate. Through stimulation of intestinal absorption of these elements, vitamin D contributes to the maintenance of adequate levels of serum calcium, and consequently to bone mineralization. ${ }^{15}$ It can be obtained exogenously through the diet, for example, from wild saltwater fish like salmon, but it is primarily produced endogenously by the action of solar ultraviolet-B radiation on the skin. ${ }^{16}$ Brazil extends from the equatorial latitudes in the north to the temperate latitudes in the south, with a large variation in sunlight levels across the country. In the south and southeast regions, which have the highest demographic densities in the country, levels of solar radiation are lower during fall and winter. This regional feature could lead to a higher prevalence of vitamin D deficiency, contributing to the development of low bone mineral density and osteoporosis. In 2013, Arantes et a ${ }^{17}$ published a study that included 1,933 postmenopausal women living in six large Brazilian cities, with a variation of 25 degrees of latitude between the northernmost city (Recife) and the southernmost city (Porto Alegre). The prevalence of vitamin D deficiency was high. When analyzed together, $17 \%$ of women had vitamin D levels $<20 \mathrm{ng} / \mathrm{mL}$ and $68.3 \%$ had vitamin D levels $<30 \mathrm{ng} / \mathrm{mL}$. Women living in cities located further north (Recife and Salvador) had significantly higher levels of 25-hydroxy vitamin D compared with women who lived in cities in southern Brazil (Rio de Janeiro, São Paulo, Curitiba, and Porto Alegre). The authors concluded that, on average, there was a decrease of $0.28 \mathrm{ng} / \mathrm{mL}$ in 25-hydroxy vitamin $\mathrm{D}$ level for each degree of latitude further south. This higher prevalence of vitamin D deficiency may be associated with a higher frequency of osteoporosis and bone fractures, although this study found no significant relationship between vitamin D levels and bone mineral density at the femoral neck and lumbar spine. ${ }^{17}$

\section{Diagnostic methods}

Postmenopausal osteoporosis can be diagnosed on the basis of clinical history alone, when a symptomatic bone fracture results from low-intensity trauma ${ }^{4}$ However, in most cases, imaging tests are needed to identify a decrease in bone mineral density or asymptomatic vertebral fractures..$^{18}$ The criteria for the classification of osteoporosis published by the WHO may be used for postmenopausal women (Table 1). The bone locations recommended for evaluation by bone densitometry are the lumbar spine, total hip, and femoral neck. The evaluation of the one-third radius site can be used for classification when measurements of the lumbar spine and proximal femur are unavailable. ${ }^{19}$

The consensus of international and Brazilian guidelines is to perform bone densitometry for all women aged $\geq 65$ years. For younger postmenopausal women, or women in the perimenopause, bone densitometry is only indicated for those with additional risk factors or conditions that are associated with a higher incidence of fractures. ${ }^{18,20,21}$ However, a recent study including 445 postmenopausal women aged 50-64 years found that the recommendations of the United States Preventive Services Task Force, one of the most widely used guidelines to determine the use of bone densitometry examination in the United States and similar to the Brazilian consensus, had a sensitivity of only $24 \%$. In other words, it is possible that many younger postmenopausal women with osteoporosis are not diagnosed in a timely manner. ${ }^{22}$ In Brazil, a mathematical tool that identifies women at higher risk of low bone mineral density and fragility fractures could help to identify women for bone densitometry screening. ${ }^{23}$

In 2002, the Brazilian Ministry of Health issued a decree to gain a better understanding of the national availability of diagnostic imaging equipment, including bone densitometers. ${ }^{24}$ According to this decree, 7.1 densitometers

Table I World Health Organization's definition of osteoporosis based on bone mineral density

\begin{tabular}{ll}
\hline Classification & T-score \\
\hline Normal & $\geq-1.0$ \\
Low bone mass (osteopenia) & Between -1.0 and -2.5 \\
Osteoporosis & $\leq-2.5$ \\
Severe or established osteoporosis & $\leq-2.5$ with one or more fractures \\
\hline
\end{tabular}

Note: Data from Kanis et al. ${ }^{19}$ 
per 1 million inhabitants should be available for the population. However, according to a study conducted by the Brazilian Institute of Geography and Statistics (IBGE) in $2009,{ }^{25}$ there are 5.6 densitometers per 1 million inhabitants, taking into account both public and private sectors. In the public sector, there are only 1.5 densitometers per 1 million inhabitants. In 2012, Hernandez et $\mathrm{al}^{26}$ published the results of a prospective study of 2,143 people aged $\geq 60$ years living in São Paulo. Among women who had private health insurance (51.3\% of the study population), $65.7 \%$ reported having osteoporosis. Among women who relied primarily on the public health system, 34.3\% reported having osteoporosis. ${ }^{26}$ These data suggest that women with private health insurance have greater availability of resources for the diagnosis of osteoporosis. However, women who are dependent on the public health system do not have sufficient access to densitometers, which can lead to delayed or missed diagnosis of osteoporosis.

Performing radiography of the spine is also of critical importance for patients with risk factors for osteoporosis because the presence of asymptomatic vertebral fractures significantly increases the risk of new vertebral and femoral neck fractures, ${ }^{27}$ and can change the therapeutic approach, especially in patients who present with osteopenia. Spinal radiographs should be performed for women who have lost $\geq 2.5 \mathrm{~cm}$ in height over a period of 2 years with associated pain or deformity in the spine, as well as for individuals with chronic use of glucocorticoids. ${ }^{28}$

\section{Treatment}

All postmenopausal women should be encouraged to maintain a healthy lifestyle, which includes physical activity and a balanced diet. Additionally, smoking and alcohol use should be addressed, because both are known risk factors for low bone mineral density. Special attention should be given to interventions to reduce the risk of falls in postmenopausal women, especially among older women with osteoporosis. Supervised exercise programs and measures to improve home safety, such as avoiding slippery rugs, stairs, and environments with low light, are known to reduce the risk of falls in the elderly. ${ }^{29}$

Adequate calcium intake should be encouraged in postmenopausal women, preferably through diet. Because calcium supplementation has a beneficial effect on bone mineral density, mineral supplements can be used in patients who do not have adequate nutrition. Calcium supplementation may also reduce the incidence of vertebral fractures, but its effects on the incidence of nonvertebral fractures remains uncertain. ${ }^{30}$ Recently, there has been concern about a possible increased risk of cardiovascular disease related to the use of calcium supplements. In 2010, Bolland et $\mathrm{al}^{31}$ published a meta-analysis that identified a $31 \%$ increase in the risk of myocardial infarction among patients receiving calcium supplementation ( $\geq 500 \mathrm{mg} / \mathrm{d}$ ). ${ }^{31}$ However, another systematic review and meta-analysis found no association between calcium supplementation and an increased risk of cardiovascular disease. ${ }^{32}$ Results from the Nurses' Health Study, ${ }^{33}$ a large prospective cohort study of 74,245 women followed for 24 years, found no association between the use of calcium supplements and an increased risk of cardiovascular disease. In fact, women who used calcium supplements had a lower incidence of ischemic heart disease. ${ }^{33}$ Therefore, the decision to recommend calcium supplementation should be made individually, taking into account individual dietary habits.

In addition to low levels of dietary calcium, Brazilian women obtain a minimal amount of vitamin $\mathrm{D}$ from their diet. Foods that are rich sources of vitamin D are not accessible to most women in Brazil, and currently, there are no vitamin D food fortification policies. ${ }^{14}$ Supplementation is warranted in patients with little exposure to solar ultraviolet-B radiation. Serum 25-hydroxy vitamin D levels are useful to determine reserves of vitamin $\mathrm{D}$ and to plan doses for supplementation. The Institute of Medicine (IOM) in the United States considers levels of 25-hydroxy vitamin $\mathrm{D} \geq 20 \mathrm{ng} / \mathrm{mL}$ sufficient to maintain bone mineral density. ${ }^{13}$ The Brazilian Society of Endocrinology and Metabolism is stricter and considers the adequate level to be $\geq 30 \mathrm{ng} / \mathrm{mL} .{ }^{34}$ For patients with very low levels of 25-hydroxy vitamin $\mathrm{D}(<20 \mathrm{ng} / \mathrm{mL})$, administration of 7,000 international units (IU) per day or 50,000 IU per week for up to 2 months is recommended..$^{35}$ According to the Brazilian Society of Endocrinology and Metabolism, women with osteoporosis should maintain levels of 25-hydroxy vitamin $\mathrm{D}>30 \mathrm{ng} / \mathrm{mL}$ and should take vitamin D supplementation of between 1,000 and 2,000 IU per day. ${ }^{34}$

For women diagnosed with osteoporosis, some form of pharmacologic therapy should be initiated. For those with densitometry values compatible with osteopenia, individual risk factors for fracture should be considered to guide treatment decisions. The Fracture Risk Assessment Tool (FRAX) developed by the WHO is now available for use in the Brazilian population, ${ }^{36}$ although there is no national consensus on the risk thresholds that should indicate initiation of drug therapy. A previous study showed that the association between age and densitometry values is as effective as the FRAX model to identify individuals at high risk of bone 
fracture. ${ }^{37}$ New studies on the use of the FRAX tool are needed before it can be used to guide decisions on whether or not to initiate drug therapy for Brazilian women.

Drugs with different mechanisms of action are available to treat postmenopausal osteoporosis. Among them are the bisphosphonates, hormone replacement therapy with estrogen, selective estrogen receptor modulators, calcitonin, strontium ranelate, denosumab, and teriparatide. The main characteristics of these drugs are described in Table 2.

The Brazilian Federal Government, through the public health system (Sistema Único de Saúde [SUS]), provides free medication through public policies aimed at ensuring the integrity of pharmacological treatment. To qualify for free medication, candidates for drug therapy must meet certain clinical criteria (Table 3). For postmenopausal women, there is a flow chart with the medications available free of charge through the SUS, and a suggested sequence for the use of these medications. ${ }^{20}$ All women should have an adequate intake of calcium and vitamin $\mathrm{D}$, and supplementation should be performed if diet is not adequate. Bisphosphonates are the first-line treatment for diagnosed osteoporosis. The oral bisphosphonates alendronate and risedronate should be used first. For women who are intolerant to oral bisphosphonates, the use of intravenous pamidronate is recommended. Raloxifene or conjugated estrogens can be used when there is a contraindication or intolerance to the use of bisphosphonates. In women with contraindications to the use of bisphosphonates, raloxifene, and estrogen conjugates, the use of calcitonin is recommended (Figure 1). Other medications that act on bone metabolism, such as teriparatide, zoledronic acid, ibandronate, strontium ranelate, and denosumab, are not provided free of charge by the SUS, because, according to the Clinical Protocol and Therapeutic Guidelines of the Ministry of Health, there is no evidence that these drugs are clinically superior to those covered by the Brazilian government program. ${ }^{20}$

\section{Analysis of the management of osteoporosis in Brazil}

National data indicate that approximately $75 \%$ of the Brazilian population do not have private health insurance and rely on the public health system (the SUS).$^{58}$ Drug treatment for osteoporosis can decrease the morbidity and mortality of the disease and can decrease costs resulting from fractures caused by low-impact trauma. Brandão et $\mathrm{al}^{59}$ analyzed data

Table 2 Drugs available to treat postmenopausal osteoporosis in Brazil

\begin{tabular}{|c|c|}
\hline & Main effects \\
\hline \multicolumn{2}{|l|}{ Bisphosphonates } \\
\hline \multirow[t]{2}{*}{ Alendronate } & $\begin{array}{l}\text { Reduces the incidence of spinal and femoral fractures by approximately } 50 \% \text { over } 3 \text { years in patients with a history } \\
\text { of prior vertebral fracture. }{ }^{38}\end{array}$ \\
\hline & Reduces the incidence of vertebral fracture by $44 \%$ in patients without a history of prior vertebral fracture. ${ }^{39}$ \\
\hline Risedronate & $\begin{array}{l}\text { Reduces the risk of vertebral fractures by } 41 \%-49 \% \text { and nonvertebral fractures by } 33 \%-39 \% \text { in patients with previous } \\
\text { fractures. }{ }^{40}\end{array}$ \\
\hline \multirow[t]{2}{*}{ lbandronate } & Reduces the incidence of vertebral fractures by approximately $50 \%$ over 3 years. ${ }^{41}$ \\
\hline & Meta-analyses suggest that it is effective in reducing nonvertebral fractures. ${ }^{42}$ \\
\hline \multirow[t]{3}{*}{ Pamidronate } & Used intravenously has similar efficacy to alendronate in improvement in bone mineral density at lumbar spine. ${ }^{43}$ \\
\hline & Effective in reducing bone loss after solid organ transplantation and in chronic users of corticoids. ${ }^{20}$ \\
\hline & "Off-label" use for osteoporosis treatment. \\
\hline Zoledronic acid & Reduces the risk of vertebral fractures by $70 \%$, femoral neck fractures by $41 \%$, and nonvertebral fractures by $25 \% .{ }^{44}$ \\
\hline Hormone therapy & Reduces the risk of clinical vertebral fractures and hip fractures by $34 \%$ and other osteoporotic fractures by $23 \% .{ }^{45}$ \\
\hline \multicolumn{2}{|l|}{ with estrogen } \\
\hline \multirow[t]{4}{*}{ Raloxifene } & Reduces the risk of vertebral fractures in women with osteopenia or osteoporosis by $30 \%-50 \%$. ${ }^{46-49}$ \\
\hline & Does not diminish the risk of nonvertebral fractures. \\
\hline & Reduces the risk of invasive estrogen-dependent breast cancer in postmenopausal women with osteoporosis ${ }^{50,51}$ \\
\hline & and/or at high risk of breast cancer. ${ }^{52}$ \\
\hline \multirow[t]{3}{*}{ Calcitonin } & Reduces the risk of vertebral fractures by $33 \%$ in patients without previous fractures. ${ }^{53}$ \\
\hline & Reduces the risk of new vertebral fractures by $36 \%$ in patients who already have a history of vertebral fracture. ${ }^{53}$ \\
\hline & Does not reduce the risk of nonvertebral fractures. ${ }^{53}$ \\
\hline \multirow[t]{2}{*}{ Teriparatide } & Reduces the incidence of vertebral fractures by approximately $65 \%$ and of nonvertebral fractures by approximately $53 \% .{ }^{54}$ \\
\hline & Because there is a theoretical risk of osteosarcoma, the medication should be used for a maximum of 2 years. ${ }^{54}$ \\
\hline \multirow[t]{2}{*}{ Denosumab } & Patients with osteoporosis who received denosumab for 3 years experienced a $68 \%$ reduction in the risk of new \\
\hline & vertebral fractures, a $20 \%$ reduction in nonvertebral fractures, and a $40 \%$ reduction in femoral neck fractures. ${ }^{55}$ \\
\hline \multirow[t]{4}{*}{ Strontium ranelate } & Reduces the risk of a new vertebral fracture by $49 \%$ after I year of treatment and by $41 \%$ after 3 years of treatment \\
\hline & in women with a prior vertebral fracture. ${ }^{56}$ \\
\hline & Reduces the risk of vertebral fractures in women without a history of previous fractures by $45 \%$, and the risk \\
\hline & of nonvertebral fractures by $16 \% .^{57}$ \\
\hline
\end{tabular}


Table 3 Criteria for the initiation of medical treatment for postmenopausal osteoporosis

Low-impact fracture of the femur, hip, or vertebrae (clinical or morphometric) radiologically confirmed

$T$-score $\leq-2.5$ at femoral neck or spine

Low bone mass ( $T$-score between -1.5 and -2.5 at the femoral neck or spine) in patients aged 70 years or more if they have suffered two or more falls in the last 6 months

Glucocorticoid treatment in a dose higher than $5 \mathrm{mg}$ of prednisone per day (or equivalent dose of another corticosteroid) for a period of 3 months or more

Notes: Data from Ministério da Saúde. ${ }^{20}$

from a historical cohort of 72,265 women using medications provided by the SUS for postmenopausal osteoporosis between the years 2000 and 2006. The average monthly per capita expenditure in the first year of treatment was approximately USD54.00, and most women used the same medication throughout the treatment period (89.8\%). Alendronate was the most commonly used drug at the initiation of therapy $(57.0 \%)$, followed by calcitonin $(24.6 \%)$, and raloxifene (15.6\%). Risedronate had a low frequency of use $(0.4 \%)$. With regard to costs, raloxifene and calcitonin were associated with the greatest expenses for the SUS..$^{59}$

Recently, Moraes et $\mathrm{al}^{60}$ published an article providing data on the expenditure of the Ministry of Health of Brazil for the treatment of osteoporosis during 2008-2010. It was found that women, who more frequently receive osteoporosis-related procedures and treatment, incur higher absolute costs than men. Women underwent 295,935 bone densitometry tests within the public health system in the 3-year period, representing a total expenditure of approximately USD8,605,000. Women also accounted for most of the drug expenditure for osteoporosis during the study period, accounting for approximately USD34,035,000, and representing $97.8 \%$ of the total drug expenditure for osteoporosis from 2008 to 2010 . However, when the total spending on osteoporosis was adjusted for the number of procedures performed, men incurred a higher average cost per procedure. Most of the procedures in men were highly complex, which may indicate a delay in the diagnosis and treatment of the disease in the male population in Brazil. ${ }^{60}$

\section{Monitoring of treatment}

Monitoring the effectiveness of osteoporosis treatment is very important, especially in Brazil, where national studies show that women have difficulty adhering to prescribed medication

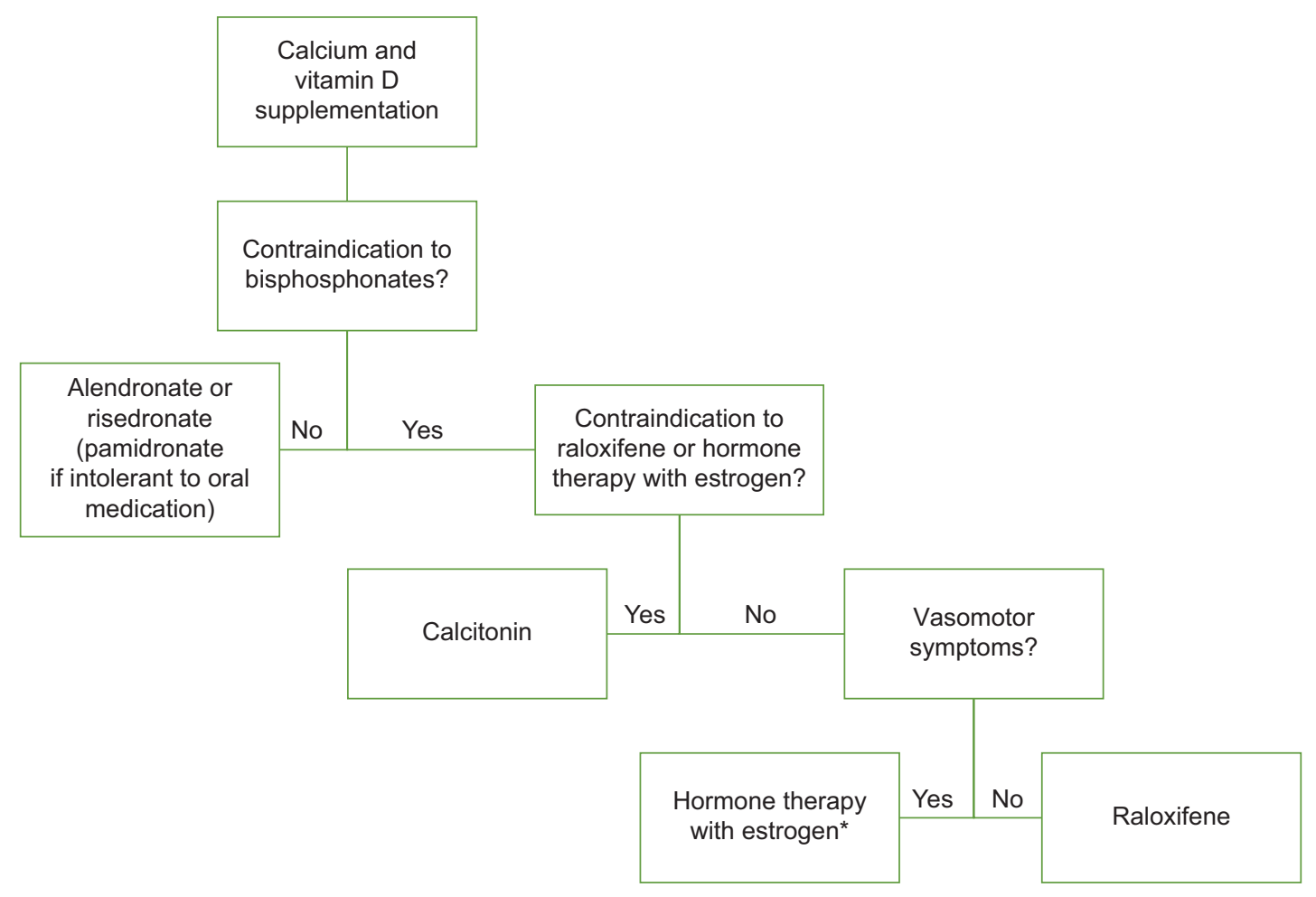

Figure I Flow chart with the medications available free of charge through SUS.

Note: *Women with an intact uterus should make use of an estrogen and progesterone association.

Abbreviation: SUS, Sistema Único de Saúde. 
regimens, which may limit the effectiveness of medications. It is estimated that $61.3 \%$ of women do not make proper use of calcium and/or vitamin D supplements, ${ }^{61}$ and that $62.4 \%$ do not use weekly bisphosphonates correctly. ${ }^{62}$ Bone densitometry is the gold standard to monitor bone mineral density. In patients receiving drug treatment for postmenopausal osteoporosis, densitometry should generally be repeated every 2 years. In cases of severe osteoporosis and in patients with a high risk of new fractures, this interval can be reduced, but there should not be less than 1 year between each examination. Annual height measurement can also be used to monitor women with postmenopausal osteoporosis. Loss of $\geq 2 \mathrm{~cm}$ in height could mean that a new vertebral fracture has occurred, indicating the need for repeat spinal radiography. ${ }^{18}$

\section{Duration of treatment}

The duration of each form of treatment should be individualized for each patient. As life expectancy increases, women will have to live for more years with osteoporosis and an increased risk of fragility fractures. Achieving a balance between the beneficial therapeutic effects and potential adverse effects arising from treatment is an ongoing challenge. Despite being the most frequently used agents, the use of bisphosphonates beyond 5 years is controversial. There is concern that prolonged use can cause a decrease in the ability of bone to remodel, resulting in damage to its microstructure. Such damage could lead to serious adverse events, such as subtrochanteric and shaft fractures, ${ }^{18}$ but this hypothesis has not yet been confirmed in randomized controlled trials. The occurrence of osteonecrosis of the jaw in patients receiving bisphosphonates is a very rare adverse event that occurs more frequently in women with cancer receiving high doses of intravenous bisphosphonates. Causality has not been established between the use of oral bisphosphonates and an increased incidence of osteonecrosis of the jaw. ${ }^{63}$ After 5 years of use, the risk of fractures should be reassessed by clinical history, radiography, and bone densitometry to define the best approach to future treatment. In Brazil, it is recommended that women who have worsening of bone mass during treatment, or $T$-score values of -3.5 or less should continue to receive bisphosphonate therapy even after 5 years of initial use..$^{20}$ In patients at high risk of bone fractures, the use of bisphosphonates for up to 10 years appears to be a favorable approach in terms of risks and benefits. ${ }^{64}$

\section{Conclusion}

Postmenopausal osteoporosis is a chronic and often asymptomatic disease. The prevalence in Brazil does not differ from that in other countries, but there is limited knowledge about the epidemiology of the disease. More population-based studies with rigorous methodology are necessary, preferably using bone densitometry to classify osteoporosis and with representative sample populations from all regions of the country. The Brazilian government provides medication for osteoporosis through the public health system free of charge, but without proper epidemiological knowledge, the implementation of public health programs is impaired. In addition, conscientization programs for health professionals about the importance of osteoporosis would also be beneficial. If not diagnosed and treated properly, postmenopausal osteoporosis can result in bone fractures, which have negative impacts for both the patient and the health care system. Efforts are needed to ensure that all women in Brazil have access to information on osteoporosis and the opportunity to receive diagnosis and treatment for the disease.

\section{Funding}

This research was carried out without any external funding.

\section{Disclosure}

The authors report no conflicts of interest in this work.

\section{References}

1. Instituto Brasileiro de Geografia e Estatística. Notícias: Em 2008, esperança de vida dos brasileiros chega a 72,86 anos. Comunicação Social, 01 de dezembro de 2009. Available from: http://saladeimprensa.ibge. gov.br/noticias?view=noticia\&id=1\&idnoticia $=1507 \&$ busca $=1 \& \mathrm{t}=2008$ esperanca-vida-brasileiros-chega-72-86-anos. Accessed November 25, 2014.

2. Schmidt MI, Duncan BB, Azevedo e Silva G, et al. Chronic noncommunicable diseases in Brazil: burden and current challenges. Lancet. 2011(4);377(9781):1949-1961.

3. NIH Consensus Development Panel on Osteoporosis Prevention, Diagnosis and Therapy. Osteoporosis prevention, diagnosis and therapy. JAMA. 2001;285(6):785-795.

4. Kanis JA. Assessment of fracture risk and its application to screening for postmenopausal osteoporosis: synopsis of a WHO report. WHO Study Group. Osteoporos Int. 1994;4:368-381.

5. Marinho BC, Guerra LP, Drummond JB, Silva BC, Soares MM. The burden of osteoporosis in Brazil. Arq Bras Endocrinol Metabol. 2014; 58(5):434-443.

6. Camargo MB, Cendoroglo MS, Ramos LR, et al. Bone mineral density and osteoporosis among a predominantly Caucasian elderly population in the city of São Paulo, Brazil. Osteoporos Int. 2005;16(11):1451-1460.

7. Martini LA, Moura EC, Santos LC, Malta DC, Pinheiro Mde M. Prevalence of self-reported diagnosis of osteoporosis in Brazil, 2006. Rev Saude Publica. 2009;43(2):107-116.

8. Pinheiro MM, Ciconelli RM, Jacques Nde O, Genaro PS, Martini LA, Ferraz MB. The burden of osteoporosis in Brazil: regional data from fractures in adult men and women - the Brazilian Osteoporosis Study (BRAZOS). Rev Bras Reumatol. 2010;50(2):113-127.

9. Pinheiro MM, Reis Neto ET, Machado FS, et al. Risk factors for osteoporotic fractures and low bone density in pre and postmenopausal women. Rev Saude Publica. 2010;44(3):479-485. 
10. Buttros Dde A, Nahas-Neto J, Nahas EA, Cangussu LM, Barral AB, Kawakami MS. Fatores de risco para osteoporose em mulheres na pós-menopausa do sudeste brasileiro [Risk factors for osteoporosis in postmenopausal women from southeast Brazilian]. Rev Bras Ginecol Obstet. 2011;33(6):295-302. Portuguese.

11. Baccaro LF, de Souza Santos Machado V, Costa-Paiva L, Sousa MH, Osis MJ, Pinto-Neto AM. Factors associated with osteoporosis in Brazilian women: a population-based household survey. Arch Osteoporos. 2013;8(1-2):138.

12. Wright NC, Looker AC, Saag KG, et al. The recent prevalence of osteoporosis and low bone mass in the United States based on bone mineral density at the femoral neck or lumbar spine. J Bone Miner Res. 2014;29(11):2520-2526

13. Institute of Medicine. Dietary Reference Intakes for Calcium and Vitamin D. Washington, DC: The National Academies Press; 2011.

14. Pinheiro MM, Schuch NJ, Genaro PS, Ciconelli RM, Ferraz MB, Martini LA. Nutrient intakes related to osteoporotic fractures in men and women - the Brazilian Osteoporosis Study (BRAZOS). Nutr J. 2009;(29);8:6.

15. Haussler MR, Whitfield GK, Haussler CA, et al. The nuclear vitamin D receptor: biological and molecular regulatory properties revealed. J Bone Miner Res. 1998;13(3):325-349.

16. Holick MF, Chen TC, Lu Z, Sauter E. Vitamin D and skin physiology: a D-lightful story. J Bone Miner Res. 2007;22(Suppl 2):V28-V33.

17. Arantes HP, Kulak CA, Fernandes CE, et al. Correlation between 25-hydroxyvitamin D levels and latitude in Brazilian postmenopausal women: from the Arzoxifene Generations Trial. Osteoporos Int. 2013; 24(10):2707-2712.

18. National Osteoporosis Foundation. Clinician's Guide to Prevention and Treatment of Osteoporosis. Washington, DC: National Osteoporosis Foundation; 2014.

19. Kanis JA, Melton LJ 3rd, Christiansen C, Johnston CC, Khaltaev N. The diagnosis of osteoporosis. J Bone Miner Res. 1994;9(8): $1137-1141$.

20. Ministério da Saúde, Brasil. Protocolo Clínico e Diretrizes Terapêuticas: Osteoporose. Portaria SAS/MS n. 451 de 09 de junho de 2014, retificada em 18 de junho de 2014. Available from: http://portalsaude.saude.gov. br/images/pdf/2014/dezembro/15/Osteoporose.pdf. Accessed January 20, 2015.

21. Nelson HD, Haney EM, Chou R, Dana T, Fu R, Bougatsos C. Screening for Osteoporosis: Systematic Review to Update the 2002 US Preventive Services Task Force Recommendation. Evidence Syntheses No 77. AHRQ Publication No 10-05145-EF-1. Rockville, MD: Agency for Healthcare Research and Quality; 2010.

22. The North American Menopause Society. 25th Annual Meeting of The North American Menopause Society October 15-October 18, 2014, Washington, DC. USPSTF Osteoporosis Screening Strategy: Confirming its predictive ability may prove challenging? (Abstract S-13). Menopause 2014;21(12):1320-1369.

23. Pinheiro MM, Reis Neto ET, Machado FS, Omura F, Szejnfeld J, Szejnfeld VL. Development and validation of a tool for identifying women with low bone mineral density and low-impact fractures: the São Paulo Osteoporosis Risk Index (SAPORI). Osteoporos Int. 2012;(23):1371-1379. Available from http://www2.unifesp.br/dmed/ reumato/sapori. Accessed November 25, 2014.

24. Ministério da Saúde, Brasil. Portaria n. 1101/GM em 12 de junho de 2002. Available from: http://dtr2001.saude.gov.br/sas/PORTARIAS/ Port2002/Gm/GM-1101.htm. Accessed November 25, 2014.

25. Instituto Brasileiro de Geografia e Estatística. Indicadores sociodemográficos e de saúde no Brasil 2009. Escassez e fartura: distribuição da oferta de equipamentos de diagnóstico por imagem no Brasil. Available from: http://www.ibge.gov.br/home/estatistica/ populacao/indic_sociosaude/2009/com_esca.pdf. Accessed November $25,2014$.

26. Hernandes ES, Lebrão ML, Duarte YA, Santos JL. Health insurance coverage of the elderly and socioepidemiological characteristics associated. Rev Saude Publica. 2012;46(6):1030-1038.
27. Ross PD, Davis JW, Epstein RS, Wasnich RD. Pre-existing fractures and bone mass predict vertebral fracture incidence in women. Ann Intern Med. 1991;114(11):919-923.

28. Associação Médica Brasileira e Conselho Federal de Medicina. Osteoporose: Diagnóstico. Projeto Diretrizes, 2011. Available from: http:// www.projetodiretrizes.org.br/diretrizes10/osteoporose_diagnostico. pdf. Accessed January 20, 2015.

29. Gillespie LD, Robertson MC, Gillespie WJ, et al. Interventions for preventing falls in older people living in the community. Cochrane Database Syst Rev. 2009;2:CD007146.

30. Shea B, Wells GA, Cranney A, et al. Calcium supplementation on bone loss in postmenopausal women. Cochrane Database Syst Rev. 2004;1: CD004526.

31. Bolland MJ, Avenell A, Baron JA, et al. Effect of calcium supplements on risk of myocardial infarction and cardiovascular events: metaanalysis. BMJ. 2010(29);341:c3691.

32. Wang L, Manson JE, Sesso HD. Calcium intake and risk of cardiovascular disease: a review of prospective studies and randomized clinical trials. Am J Cardiovasc Drugs. 2012;12(2):105-116

33. Paik JM, Curhan GC, Sun Q, et al. Calcium supplement intake and risk of cardiovascular disease in women. Osteoporos Int. 2014;25(8):2047-2056.

34. Maeda SS, Borba VZ, Camargo MB, et al. Recommendations of the Brazilian Society of Endocrinology and Metabology (SBEM) for the diagnosis and treatment of hypovitaminosis D. Arq Bras Endocrinol Metabol. 2014;58(5):411-33.

35. Holick MF, Binkley NC, Bischoff-Ferrari HA, et al. Evaluation, treatment, and prevention of vitamin D deficiency: an Endocrine Society clinical practice guideline. J Clin Endocrinol Metab. 2011;96(7):1911-1930.

36. Kanis JA, Johnell O, Oden A, Johansson H, McCloskey E. FRAX and the assessment of fracture probability in men and women from the UK. Osteoporos Int. 2008;(19):385-397.

37. Ensrud KE, Lui LY, Taylor BC, et al; Study of Osteoporotic Fractures Research Group. A comparison of prediction models for fractures in older women: is more better? Arch Intern Med. 2009;169(22):2087-2094.

38. Black DM, Cummings SR, Karpf DB, et al. Randomised trial of effect of alendronate on risk of fracture in women with existing vertebral fractures. Fracture Intervention Trial Research Group. Lancet. 1996;348(9041):1535-1541.

39. Cummings SR, Black DM, Thompson DE, et al. Effect of alendronate on risk of fracture in women with low bone density but without vertebral fractures: results from the Fracture Intervention Trial. JAMA. 1998;280(24):2077-2082.

40. Reginster J, Minne HW, Sorensen OH, et al. Randomized trial of the effects of risedronate on vertebral fractures in women with established postmenopausal osteoporosis. Vertebral Efficacy with Risedronate Therapy (VERT) Study Group. Osteoporos Int. 2000;11(1):83-91.

41. Chesnut III CH, Skag A, Christiansen C, et al. Effects of oral ibandronate administered daily or intermittently on fracture risk in postmenopausal osteoporosis. J Bone Miner Res. 2004;19(8):1241-1249.

42. Harris ST, Blumentals WA, Miller PD. Ibandronate and the risk of non-vertebral and clinical fractures in women with postmenopausal osteoporosis: results of a meta-analysis of phase III studies. Curr Med Res Opin. 2008;24(1):237-245.

43. Heijckmann AC, Juttmann JR, Wolffenbuttel BH. Intravenous pamidronate compared with oral alendronate for the treatment of postmenopausal osteoporosis. Neth J Med. 2002;60(8):315-319.

44. Black DM, Delmas PD, Eastell R, et al. Once-yearly zoledronic acid for treatment of postmenopausal osteoporosis. N Engl J Med. 2007; 356(18):1809-1822.

45. Rossouw JE, Anderson GL, Prentice RL, et al. Risks and benefits of estrogen plus progestin in healthy postmenopausal women: principal results from the Women's Health Initiative randomized controlled trial. JAMA. 2002;288(3):321-333.

46. Ettinger B, Black DM, Mitlak BH, et al. Reduction of vertebral fracture risk in postmenopausal women with osteoporosis treated with raloxifene: results from a 3-year randomized clinical trial. Multiple Outcomes of Raloxifene Evaluation (MORE) Investigators. JAMA. 1999;282(7):637-645. 
47. Siris E, Adachi JD, Lu Y, et al. Effects of raloxifene on fracture severity in postmenopausal women with osteoporosis: results from the MORE study. Multiple Outcomes of Raloxifene Evaluation. Osteoporos Int. 2002;13(11):907-913.

48. Ensrud KE, Stock JL, Barrett-Connor E, et al. Effects of raloxifene on fracture risk in postmenopausal women: the Raloxifene Use for the Heart Trial. J Bone Miner Res. 2008;23(1):112-120.

49. Kanis JA, Johnell O, Black DM, et al. Effect of raloxifene on the risk of new vertebral fracture in postmenopausal women with osteopenia or osteoporosis: a reanalysis of the Multiple Outcomes of Raloxifene Evaluation trial. Bone. 2003;33(3):293-300.

50. Martino S, Cauley JA, Barrett-Connor E, et al. Continuing outcomes relevant to Evista: breast cancer incidence in postmenopausal osteoporotic women in a randomized trial of raloxifene. J Natl Cancer Inst. 2004;96(23):1751-1761.

51. Cummings SR, Eckert S, Krueger KA, et al. The effect of raloxifene on risk of breast cancer in postmenopausal women: results from the MORE randomized trial. Multiple Outcomes of Raloxifene Evaluation. JAMA. 1999;281(23):2189-2197.

52. Vogel VG, Costantino JP, Wickerham DL, et al. Effects of tamoxifen vs raloxifene on the risk of developing invasive breast cancer and other disease outcomes: the NSABP Study of Tamoxifen and Raloxifene (STAR) P-2 trial. JAMA. 2006;295(23):2727-2741.

53. Chesnut $\mathrm{CH}$ 3rd, Silverman S, Andriano K, et al. A randomized trial of nasal spray salmon calcitonin in postmenopausal women with established osteoporosis: the prevent recurrence of osteoporotic fractures study. PROOF Study Group. Am J Med. 2000;109(4):267-276.

54. Neer RM, Arnaud CD, Zanchetta JR, et al. Effect of parathyroid hormone (1-34) on fractures and bone mineral density in postmenopausa women with osteoporosis. N Engl J Med. 2001;344(19):1434-1441.
55. Cummings SR, San Martin J, McClung MR, et al. Denosumab for prevention of fractures in postmenopausal women with osteoporosis. N Engl J Med. 2009;361(8):756-765.

56. Meunier PJ, Roux C, Seeman E, et al. The effects of strontium ranelate on the risk of vertebral fracture in women with postmenopausal osteoporosis. N Engl J Med. 2004;350(5):459-468.

57. Reginster JY, Seeman E, De Vernejoul MC, et al. Strontium ranelate reduces the risk of nonvertebral fractures in postmenopausal women with osteoporosis: Treatment of Peripheral Osteoporosis (TROPOS) study. J Clin Endocrinol Metab. 2005;90(5):2816-2822.

58. Bahia L, Costa A, Fernandes C, Luiz RR, Cavalcanti MdLT. Segmentation of the demand of the plans and private insurances of health: an analysis of the information of PNAD/98. Ciênc Saúde Coletiva. 2002;7(4):671-686.

59. Brandão CM, Ferré F, Machado GP, et al. Public spending on drugs for the treatment of osteoporosis in post-menopause. Rev Saude Publica. 2013;47(2):390-402.

60. Moraes LF, Silva EN, Silva DA, Paula AP. Expenditures on the treatment of osteoporosis in the elderly in Brazil (2008-2010): analysis of associated factors. Rev Bras Epidemiol. 2014;17(3):719-734.

61. de Castro Gomes DA, Valadares AL, Pinto-Neto AM, Morais SS, CostaPaiva L. Ability to follow drug treatment with calcium and vitamin D in postmenopausal women with reduced bone mass. Menopause. 2012;19(9):989-994.

62. Gomes DC, Costa-Paiva L, Farhat FC, Pedro AO, Pinto-Neto AM. Ability to follow anti-reabsorptive drug treatment in postmenopausal women with reduced bone mass. Menopause. 2011;18(5):531-536.

63. Abrahamsen B. Adverse effects of bisphosphonates. Calcif Tissue Int. 2010;86(6):421-435.

64. Watts NB, Diab DL. Long-term use of bisphosphonates in osteoporosis J Clin Endocrinol Metab. 2010;95(4):1555-1565.
Clinical Interventions in Aging

\section{Publish your work in this journal}

Clinical Interventions in Aging is an international, peer-reviewed journal focusing on evidence-based reports on the value or lack thereof of treatments intended to prevent or delay the onset of maladaptive correlates of aging in human beings. This journal is indexed on PubMed Central, MedLine,

\section{Dovepress}

CAS, Scopus and the Elsevier Bibliographic databases. The manuscript management system is completely online and includes a very quick and fair peer-review system, which is all easy to use. Visit http://www.dovepress. com/testimonials.php to read real quotes from published authors. 